\title{
Violent Crime and the Overmilitarization of US Policing
}

\author{
Federico Masera*
}

\begin{abstract}
Using new data at the police department level, I propose an identification strategy to estimate the causal effect that police militarization has on reducing violent crime. I show that previous estimates are likely to be contaminated by unobserved factors that simultaneously determine militarization and violent crime. Upon addressing this issue, I find an effect that is 20 times as large as previously estimated. I then find that one fourth of the effect of militarization is due to the displacement of violent crime to neighboring areas. Police departments overmilitarize because they do not consider this externality. These new findings have significant implications for the policy debate concerning the costs and benefits of police militarization.
\end{abstract}

*I thank Luis Corchon for his guidance and support. I am also grateful to Paolo Buonanno, Irma Clots-Figueras, Federico Curci, Gianmarco Daniele, Nicola Esposito, Jesus Fernandez-Huertas, Pauline Grosjean, Richard Holden, Olivier Marie, Jaime Millan, Luigi Minale, Emily Owens, Arnaud Philippe, Paolo Pinotti, Imran Rasul, Jan Stuhler, Hasin Yousaf and the participants of the 2015 MOMA meeting in Alicante, 2016 Workshop on the Economics of Organized Crime, 2016 Transatlantic Workshop on the Economics of Crime, 2016 Econometric Society Winter Meeting and 2016 Spanish Economic Association. University of New South Wales - Email: f.masera@unsw.edu.au 


\section{Introduction}

The distribution in recent years of over one billion dollars in military equipment to police departments across the US has led to an unprecedented level of police militarization. Today two thirds of the US population lives under the jurisdiction of a local enforcement agency that is equipped with military weapons. 1$]$ At least 200 operations are deployed by the police each day using this equipment [Kraska (2007); Coyne and Hall-Blanco (2016)]. These rapid changes in the way public security is provided are not confined to the US. As terrorist threats have recently escalated in Europe, many countries have increased their use of military equipment $\left.\right|^{2}$ In the developing world, police departments have been heavily militarized for many years, and in some cases, the army is directly engaged in fighting crime.$^{3}$

In the US, police militarization has become heavily debated following the highly visible use of military equipment by the police during the riots in Ferguson, Missouri in 2014. The debate continued in recent years after an executive order signed by President Obama restricted the use of military equipment by the police. In August 2017, President Trump issued an executive order reverting those restrictions stating that the US faced the "threat of rising crime", 4

The policy debate surrounding the appropriate use of military equipment by the police has sparked substantial academic interest. In the last years, due to the availability of new data, scholars have started studying the 1033 Program: the main program that transfers military equipment to police departments in the US. Carriere and Encinosa (2017) shows a negative correlation between military equipment and assaults on the police at the state level. The relation goes in the opposite di-

\footnotetext{
${ }^{1}$ These statistics are calculated using only data from the 1033 Program, the main federal program that allows local enforcement agencies to acquire military weapons in the US. Alternatively, local law enforcement agencies may buy military weapons using their finances or the Department of Homeland Security grants.

${ }^{2}$ Operation Sentinelle was launched in France after the Charlie Hebdo massacre of January 2015 with 10,000 military forces sent across France. In 2016 both Belgian and Dutch police forces were allowed to carry heavy military guns when protecting high-risk sites.

${ }^{3}$ The militarization of public security is particularly present in Latin America. Examples can be found with Mexico where President Calderon send 50,000 soldiers to fight drug-trafficking criminals, the PMOP initiative in Honduras against street gangs and Venezuelan President Maduro's decision in 2013 to send 3,000 soldiers to combat crime in Caracas.

${ }^{4}$ President Obama signed Executive Order 13688 reformed the use of military equipment by the police in January 2015. President Trump reversed this decision with Executive Order 13809 in August 2017.
} 
rection when looking at operational militarized items as sonars and radars. Delehanty et al. (2017) at the county level and Lawson (2018) at the police department level find a positive relation between civilian casualties and military equipment transferred through the 1033 program. Mummolo (2018) shows that militarized police units are more often deployed in communities with a large share of black people. He finds no relationship between militarization of the police and officer safety or crime but militarization is negatively related to police reputation.

Closer to my paper, Bove and Gavrilova (2017) and Harris et al. (2017) study the effects of militarization at the county level in an instrumental variable setting. Bove and Gavrilova (2017) predicts militarization by interacting time variation in aggregate military spending with the fraction of years a county has received military equipment and shows that counties that tend to receive more military aid experienced a reduction in street-level crime. Harris et al. (2017) first predicts the militarization of the police in a county using the centroid distance to 1033 Program storage facilities, whether the county is in a high-intensity drug trafficking area and the size of the county. The predicted militarization is then used to show that militarization reduces citizen complaints, assaults on police officers and some types of crime.

Using new data at the police department level, I contribute to this discussion in two ways: First, I propose a new identification strategy to estimate the causal effects of militarization on violent crime. I show that previous estimates are likely to be contaminated by unobserved factors that determine simultaneously militarization decisions and violent crime. Once addressing this concern, I find results that are at least 20 times as large as previously estimated. Second, I identify significant geographical spillovers by showing that criminals react to militarization by moving their criminal activities to neighboring areas. Given the decentralized nature of militarization decisions, police departments overmilitarize because they do not consider this spillover. This result, more generally, illustrates a problem in the current design of the US police system that, in some regards, is a collection of uncoordinated police forces with jurisdiction over small geographic areas. Under this system, policing decisions are suboptimal because they do not take into account the externalities imposed onto neighboring police departments. 
To estimate the effects of militarization I study the 1033 Program: Established in 1996, the program only started redistributing large quantities of military equipment in 2010. This happened after the withdrawal from the Afghan and Iraqi wars led to the arrival of vast quantities of military equipment to the US. $5^{5}$ Similarly to Harris et al. (2017), I estimate the effect of military equipment in an instrumental variable setting using the fact that, when returning from war, military equipment is available at various disposition centers across the US. These disposition centers are storage facilities located in military bases that in 1996 when the 1033 Program was established, were assigned to the program. The effective cost of military equipment acquired from the 1033 Program is increasing with distance to the disposition centers. There are two main reasons for this cost: First, police departments must cover all transportation costs but do not pay for the cost of the military equipment. Second, every police department must appoint an officer to personally inspect the military items before these are requested. Inspections can be cheaper and more frequent if the police department is located near a disposition center.

Due to these costs, I expect that, after the withdrawal from the wars, police departments close to these storage facilities receive more military equipment. This difference in militarization trends can then be used in a Difference-in-Differences framework as a first stage to predict militarization exogenously. In order to use this variation in a first stage to causally estimate the effects of militarization on violent crime the following identifying assumption must hold: After 2009, any difference in violent crime trends between police departments close and far away from disposition centers is only due to their differential militarization.

The main threat to this identifying assumption is that disposition centers are storage facilities located in military bases. Because of this, police departments close to disposition centers are also, by definition, close to a military base. If police departments around military bases differ in ways that determine trends in violent crime rates the identification assumption is not satisfied. Of particular concern is the fact that military troops return to military bases and the timing of this return coincides with the increase in the militarization of the police. Furthermore, I show

\footnotetext{
${ }^{5}$ Given that, from 2015, the Executive Order 13688 introduced many legislative changes to the 1033 Program the analysis includes data only up to 2014 .
} 
that before the withdrawals from the war police departments close to and far away from military bases were different in many observable characteristics related to crime. These differences shed some doubts on the validity of the identification strategy based on the comparison between police departments close and far away from a disposition center. ${ }^{6}$

One of the main contributions of this paper is to improve on the literature by solving this identification issue. I do so by exploiting the fact that only some military bases were selected to be disposition centers in 1996, when the 1033 Program was created. I then take into account the effect that being close to a military base has on violent crime trends by controlling for the closeness to a military base multiplied by year dummies..$^{7}$ Because of this, the first stage is a Difference-inDifferences equation where the only variation used to exogenously predict militarization is based on the comparison between police departments close to a disposition center with those close to the other military bases. By doing so results are not contaminated by unobservables that are common to police departments close to military bases.

To understand the exogeneity of this instrument is important to notice that the selection of military bases was made in 1996 while I exploit variation around the withdrawal from the wars that happened in 2010. The location of the disposition centers is likely not to have been actively selected in favor of areas that will observe, 14 years later, decreases in violent crime. Additionally, in Section 4.3, I provide evidence that, for the instrumental variable estimation, the selection of military bases can be taken as good as random. I do so by showing that police departments close to disposition centers and those close to other military bases were similar in levels and trends of many observables before the withdrawal from the wars and started only diverging in 2010 .

Furthermore, I contribute to the literature by controlling for the geographical spillovers that the militarization of a police department imposes on its neighbors. Because of this, I can identify the direct effect of militarization and not confound it with the spillovers coming from neighboring police departments. Additionally, in contrast with all the previous papers, I do not control for any

\footnotetext{
${ }^{6}$ In the Appendix I show that a similar problem arises when using the fraction of years a positive amount of military equipment is received as cross-sectional variation as used in Bove and Gavrilova (2017).

${ }^{7}$ I use this instrumental variable technique also in Masera(2019) to estimate the effects of the militarization of the police on killings by the police and police safety.
} 
observables that may generate bad control bias. Finally, I can avoid some non-random measurement error in militarization thanks to the more detailed data on police militarization at the police department level. In particular, I avoid the problem of overrepresenting policing resources in a county that includes a state capital. This problem arises because most state and federal agencies are generally located in the state capital, but their jurisdiction is broader than a county.

The estimates imply that for each dollar per capita of military equipment in possession of a police department, violent crime is reduced in average by $8.1 \%$. This estimate suggests that the 1033 Program has prevented 2 million violent crimes since its inception in 1996. Most of the prevented crimes have been concentrated in the last few years when militarization has become particularly widespread. Conservative cost estimates imply that militarization has prevented 86 billion US dollars in costs to the victims of violent crimes and the US justice system.

In order to understand the economic mechanism generating this result I follow the classical Becker (1968) framework; individuals choose whether or not to commit a criminal act by comparing the difference between the expected costs and benefits of criminal activity to the net benefits of the best legal alternative. In equilibrium, we observe low levels of crime if the expected costs of crime are high, the expected benefit from criminal activities are low, or the net benefit of the best legal alternative are high. There is no evidence to suggest that militarization directly affects the benefits of legal activities or the expected benefits of crime. Instead, militarization may increase the expected costs of crime by increasing the probability of being caught by the police. This change in costs is in line with anecdotal evidence provided by Balko (2014) and American Civil Liberties Union (2014) that show how after a police department gets militarized they increase the number of "Special Weapons and Tactics" (SWAT) operations. These are operations that are deployed when the circumstances are deemed as high risk and exceeds the capabilities of traditional law enforcement. As shown by Mummolo (2018) in the case of Maryland, 64\% of these operations end in an arrest. Militarization increases the probability of arresting a criminal because it gives the police a chance to attempt an arrest even in a situation where a traditional law enforcement operation could not be deployed because too risky. 
I provide additional evidence in line with the rational criminal model of Becker (1968) by showing that criminals react to the militarization of a police department by shifting their criminal activities to neighboring areas that are less militarized. Finally, I provide further evidence that the estimated effect is, at least in part, due to a change in the behavior of criminals by studying if incapacitation or deterrence are driving the effect that militarization has on violent crime. Incapacitation happens when as police get more militarized, arrests increase, leading to fewer criminals circulating in the cities and consequently fewer crimes committed. Deterrence instead arises when a rational agent observes the militarization of police and stops committing crimes. For detecting which mechanism is at play, it is important to notice that, if the effect is entirely due to incapacitation, arrests should increase due to the militarization of the police. Instead, if the mechanism is deterrence, we should observe a decrease in arrests. In line with deterrence, I show that militarization decreases arrests of violent crimes.

The results displayed in this paper are more broadly related to the literature that studies the effects of policing on crime. The most recent literature review can be found in Chalfin and Mccrary (2017). Most related to my analysis are studies that exploit quasi-experiments that attempt to uncover the elasticities of crime to changes in policing. The main threat for credible identification in this literature is the endogeneity of policing. The main concern is that, when police departments expect increases in crime, they boost their policing efforts, thus confounding any potential negative effects of policing on crime.

The first paper attempting to address this endogeneity problem is Levitt (1997), which uses the timing of mayoral and gubernatorial elections as an instrument from changes in policing. More recent examples in this literature are Di Tella and Schargrodsky (2004) and Draca, Machin and Witt (2011) that use terrorist attacks in Buenos Aires and London and the subsequent deployment of police in specific areas of these cities as an exogenous shock to policing. Evans and Owens (2007), Machin and Marie (2011) and Mello (2019) use variation in the allocation of additional policing resources in certain cities. Blanes i Vidal and Kirchmaier (2018) exploits discontinuities around division boundaries in the distance between the location where the crime was committed and police 
stations. This literature shows that an increase in policing is generally effective at reducing crime and increasing the probability of arrests. The main contribution to this literature is the study of a specific change in policing: the use of military weapons by the police. Furthermore, I study the effect on violent crime. This type of crime is one of the most costly for society but there is little existing evidence that policing may deter these types of crimes. Additionally, I uncover some geographical displacement effects that are in line with classical theories of rational criminals, but for which there has previously been very little empirical evidence.

The structure of the paper is as follows: In Section 2, I describe the data and how the 1033 Program works. Section 3 presents the econometric strategy. Section 4 presents the main results and discusses the validity of the identifying assumption. In Section 5, I explore the potential mechanisms that could generate these results. Finally, I conclude in Section 6.

\section{The 1033 Program and Data Sources}

The defense and logistics agency (DLA) is a US combat logistics agency that provides a wide range of logistics, acquisition and technical services to the Army, Marine Corps, Navy, Air Force and other federal agencies. Of particular interest to the analysis are the services they provide under the reutilization, transfers, and donation section. This section of the DLA redistributes military equipment that the Department of Defense (DoD) declares as excess to its needs. These items are then turned-in to one of DLA's disposition centers that serve as a storage facility. Once these items are received, they enter a one week accumulation period, where the items are inspected and cataloged. Then DoD's exclusive screening period starts when only DoD agencies can search for military equipment. After that, a 21 days screening period starts, when police departments can search for excess military equipment. In order to participate in the screening police departments must first apply to the 1033 Program. The application must be approved by the 1033 Program state coordinator and the DLA. When a police department is interested in a piece of military equipment they send appointed official to visit the DLA disposition site where the item is located. The official 
screens the military equipment and if interested in any item places a request. The item must have a justification and be approved by the state coordinator and the DLA. The police department that receives approval for property transfer must cover all transportation costs and potential repair costs but does not pay for the cost of the item. 8

The DLA dataset has information on the type of the item, the market value, the date of the transfer and the name of the receiving enforcement agency for all the military equipment transferred through the 1033 Program. The analysis is confined to the lowest level of law enforcement in the US.9 Since the inception of this program in 1998, more than 8000 law enforcement agencies have enrolled in this program. Since 2010, there has been a spike in the use of the 1033 Program. As shown in Figure 1, the total value of the items transferred to police departments by the 1033 Program has gone from a few million dollars every year to almost 600 million dollars in 2014. Furthermore, as reported by the American Civil Liberties Union (American Civil Liberties Union (2014)), in this period no police department has ever returned the military equipment back to the DLA. Therefore we can safely assume that once received these items remain part of the stock of military equipment in possession of the police department.

With this information, I then build the value of the stock of military equipment available to all police departments at any point in time by summing up the value in dollars of the military equipment received up to that point by the police department. The baseline measure of militarization used will be the stock of the value of military equipment divided by the population under the jurisdiction of the police department 10

\footnotetext{
${ }^{8}$ From the US house hearing held the 13th of November 2014 called "The Department of Defense Excess Property Program in Support of US Law Enforcement Agencies: An Overview of DOD Authorities, Roles, Responsibilities, and Implementation of Section 1033 of the 1997 National Defense Authorization Act" it has emerged that the state coordinators of the 1033 Program rarely deny requests for military equipment.

${ }^{9}$ At the lowest level of law enforcement in the US there are more 16000 agencies. More than $80 \%$ of these agencies are police departments. Other types of agencies are sheriff departments, tribal agencies and special district agencies. For ease of exposure throughout the paper I will call all these agencies police departments.

${ }^{10}$ Is plausible to think that the value of an item received by a police department may decrease over time. I take into account this devaluation of the items in the Appendix and show how results are robust to this alternative definition of the militarization of a police department.
} 


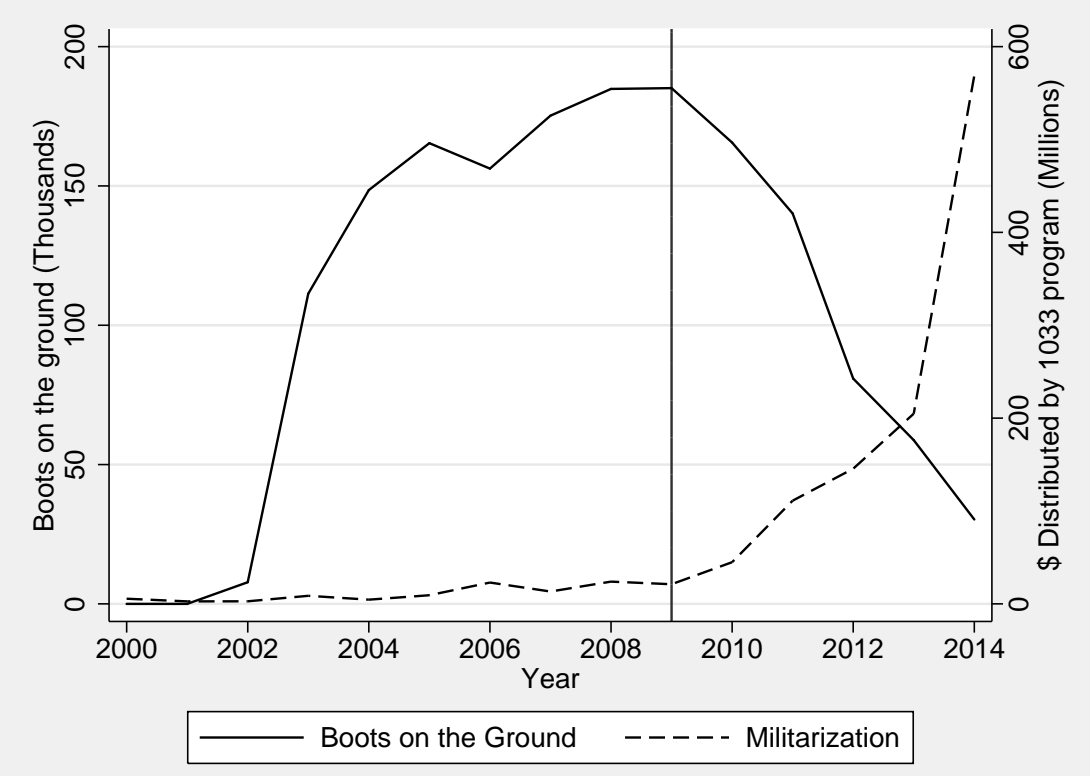

Figure 1: Value of the items transferred by the 1033 Program to police departments (dotted line) and yearly average boots on the ground in Afghanistan and Iraq (solid line). To the right of the vertical line (after 2009) starts the inflow of item from the withdrawal from the wars.

The average militarization per capita in 2009 was of 44 cents per capita. By 2014 this number increased to 3 dollars and 24 cents. In 2009, only $8.6 \%$ of the population lived under the jurisdiction of a police department that had more than 1 dollar per capita in military equipment. By 2014 this number more than tripled with $31 \%$ of the population living under these police departments.

The types of military equipment transferred through the 1033 Program are extremely varied, with almost 7,800 different types of items. Military vehicles make up almost 55\% of the total value that has been transferred. The most common vehicles are mine-resistant vehicles and armored trucks. Around $40 \%$ of the value is composed of military weapons and equipment: assault rifles, night vision equipment, camouflage and body armor are some of the most common items. The remaining $5 \%$ is comprised of non-tactical items that include computers, electricity generators, and recreational and gymnastic equipment 11

I then use the name of the police department to merge the militarization data with the Uniform

\footnotetext{
${ }^{11}$ These military items may differ substantially in their effects on crime. Unfortunately, the identification strategy used in this paper is not able to be used to capture the heterogeneous effects that different types of militarization may have. In the Appendix I discuss more in-depth the problems related to the identification of this heterogeneity and provide some preliminary evidence of the differential effects of military equipment and vehicles.
} 
Crime Reporting (UCR) statistics produced by the FBI. This dataset has been published since 1958 and collects data on crimes in the US 12

\section{Econometric Framework}

I study the effect of the militarization of a police department on the violent crime rate. The crimes that are considered violent by the FBI are murder, rape, robbery, and assaults. Formally, I would like to estimate the following equation.

$$
v c_{i, t}=\alpha_{i}+\alpha_{t}+\beta_{1} m_{i, t}+\beta X_{i, t}+\varepsilon_{i, t}
$$

where $i$ identifies the police department, $t$ the year, $v c_{i t}$ is the rate of violent crime per 1,000 inhabitants and $m i l_{i, t}$ is the dollar value of the stock of military equipment divided by the jurisdiction population.

As usual in the literature that studies how some characteristic of policing affect crime the identification of causal effects is problematic. First, are problems related to reverse causality, where police departments in which crime rate are increasing tend to demand more military equipment. Secondly, there are many observable and unobservable characteristics of a police jurisdiction that determine contemporaneously crime and the demand for military equipment. A preliminary analysis of the data shows how the militarization of the police is not uniformly spread across the US. In particular, the police departments that tend to be more militarized come from rural counties in Republican states with high percentages of white citizens and high levels of unemployment. In order to overcome these problems and uncover the causal effect of the militarization of the police on violent crime, I will use some characteristic of the structure of the 1033 Program that let me exploit some exogenous cross-sectional and time variation in the use of the program.

\footnotetext{
${ }^{12}$ Users of the UCR dataset have noted the existence of record errors in the UCR dataset. To clean the FBI dataset I follow a regression procedure similar to Evans and Owens (2007) and Mello (2019). For each variable I first fit a trend with bandwidth two. I then compute the absolute value of the percent difference between the observed and the predicted value. I then replace as missing the observations in the top $1 \%$ of the percent difference. Furthermore, between 2007 and $20143.6 \%$ of the population of the contiguous US was under the jurisdiction of a police department that did not report violent crimes. Instead of imputing this data I eliminate these observations from the analysis. Comparing the names of police departments in the UCR dataset and the 1033 Program I match $98 \%$ of the contiguous U.S. population.
} 
First of all, I use the fact that the amount of excess military equipment available to redistribute via the 1033 Program is particularly high when a US military mission ends. In the time frame of interest, the main US military operation was the "Operation Enduring Freedom", which started in October 2001 with the invasion of Afghanistan and then expanded in March 2003 in Iraq. As shown in Figure 1, the military involvement in Iraq and Afghanistan steadily increased, with a first peak reached in February of 2005 with 181,500 soldiers on the ground. After that, the level of boots on the ground was maintained for a few years until the surge of US forces called to Iraq by then US president George W. Bush in January of 2007. The number of troops increased, reaching a peak in August of 2009 when 195,200 soldiers were on the ground in Iraq and Afghanistan. From the end of 2009, the US started a slow withdrawal from Iraq, followed with a withdrawal from Afghanistan that started in early 2012. As shown in Figure 1, the return of troops in late 2009 coincides with the start of the exponential increase in military equipment distributed by the 1033 Program to police departments. The timing and the speed of the withdrawal from the war allow me to predict the time variation of aggregate military equipment distributed in the US.13

Similarly to Harris et al. (2017) I will then exploit the fact that police departments close to DLA disposition centers have easier access to military equipment. The reason for this is that the costs of acquiring items are increasing with the distance to the disposition center where the item is located. First, because, when a police department acquires a military item through the 1033 Program, the only direct cost to the department is the transportation of military equipment that has to be arranged from the DLA disposition center to the police department. Secondly, before the acquisition of an item, an agent appointed by the police department has to go to the disposition center to screen the item of interest and inspect its conditions. It is important to remember that most of the items transferred via the 1033 Program have been already used in the Iraqi and Afghan wars and their conditions may vary. Potentially, these items may require repairs, and all repair

\footnotetext{
${ }^{13} \mathrm{~A}$ more direct option is to use the total amount of equipment distributed in year $t\left(m i l_{t}\right)$ as time variation. The main problem with this specification is the timing of the increase in $m i l_{t}$ may be driven by an increase in the demand for military equipment due to changes in violent crime in the US. To rule out this option, my preferred specification uses the withdrawal from the wars as an exogenous shock in the supply of military equipment. Results using mil $l_{t}$ as time variation are reported in the Appendix
} 
costs have to be sustained by the police department. The screening process is then essential for police departments to avoid incurring in these repair costs. Additionally, the process of screening is rapid, by law, lasting a maximum of 21 days. Being able to go to inspect the military equipment of interest quickly is of fundamental importance for a police department. Because of these reasons, police departments close to the disposition centers are prone to ask more and receive more items from the 1033 Program. Figure 2 shows the location of all police departments and the 69 DLA disposition centers that participate in the 1033 Program in the contiguous US. As shown in the map, disposition centers are spread out throughout the US, the median distance of a police department from the closest disposition center is $107 \mathrm{~km}$.

I then combine these two sources of variation (one in time and the other cross-sectional) to try to exogenously predict the militarization of all police departments. This is done with the objective of then using this first stage estimate in an instrumental variable setting to estimate the causal effect of militarization on crime.

The general specification of the first stage is the following:

$$
m i l_{i, t}=\alpha_{i}+\alpha_{t}+\beta_{1} e q p_{t} * \text { closeness }(\text { disp.center })_{i}+\beta X_{i, t}+\varepsilon_{i, t}
$$

where $e q p_{t}$ measures the availability of excess military equipment as proxied by the difference from the peak of the boots on the ground in Iraq and Afghanistan that was reached in 2009 and the subsequent years. This measure $e q p_{t}$ has been then normalized to 1 in 2014 . Formally $e q p_{t}$ is defined below, where boot $s_{t}$ is the number of boots on the ground that the US military has deployed in Iraq and Afghanistan as shown in Figure $1{ }^{14}$

$$
\text { eqp }_{t}= \begin{cases}0 & \text { if } t<2010 \\ \frac{\text { boot }_{2009}-\text { boots }_{t}}{\text { boots }_{2009}-\text { boots }_{2014}} & \text { if } t \geq 2010\end{cases}
$$

The variable closeness (disp.center $)_{i}$ can be calculated in many ways using the information shown in Figure 2 on the locations of the police department and the DLA disposition centers.

\footnotetext{
${ }^{14}$ Military equipment has returned to the US even before 2010. The time variation in this first stage should be interpreted in an intention to treat framework many factors influence the aggregate amount of military equipment received by police departments, and I only use the variation produced by the withdrawal from the wars that started at the end of 2009.
} 
Some natural candidates for the function closeness(.) are the distance from the police department to the closest disposition center, a dummy indicating whether a disposition center can be found within a certain radius from the police department, or counting the number of disposition centers around a police department.

The main identification assumption behind this strategy is that changes in violent crime between years of high availability and low availability of equipment are not different between police departments close to and far away from a disposition center, other than through the military equipment received by them. The main threat to the identification strategy comes from the fact that disposition centers are located in military bases that have been selected by the National Defense Authorization Act of 1997 as DLA disposition centers for the 1033 Program. If police departments around military bases differ in unobservables that determine changes in violent crime rates this will invalidate the identification strategy.

When comparing observable characteristics of these police departments this seems to be a valid concern. For example, police departments close to a military base are less often headed by a sheriff, are considerably larger, and have a larger and less educated criminally active population. One difference that is particularly important for the identification strategy is that police departments close to a military base tend to have higher violent crime rates. These differences shed some doubts on the validity of comparing police departments close and far away from disposition centers because it would be difficult to identify whether any changes in violent crime are due to militarization or pre-existing differences between these police departments ${ }^{15}$ Additionally, police departments close to a military base may differ from those far away because of shocks directly generated by the withdrawal from the Afghan and Iraqi war. Of particular concern is the fact that military troops return specifically to military bases and the timing of this return is used for the construction of the variable $e q p_{t}$. Numerous studies have shown that conscription into the military and exposure to combat situations may have subsequent effects on violent and criminal behavior (Rohlfs (2010); Galiani, Rossi and Schargrodsky (2011); Sreenivasan et al. (2013); Anderson and Rees (2015);

\footnotetext{
${ }^{15}$ Results are reported in Table 2 comparing column "Treated (1)" with "Not Treated (3)".
} 
Cesur and Sabia (2016)).

I address this issue in an empirical framework where the only comparison used to identify the effect of militarization on violent crime is between police departments that differ in the closeness to disposition centers, and not in their closeness to a military base. To achieve this I always control for the closeness of a police department to a military base (where a military base may or may not be a DLA disposition center) multiplied by year dummies. With this specification I can control for any time-varying unobservables common to police departments close to military bases that affect militarization and violent crime.

Formally, I will estimate the following two stages in an instrumental variable setting:

First Stage:

mil $_{i, t}=\alpha_{i}+\alpha_{t}+\beta_{1}$ eqp $_{t} *$ closeness $(\text { disp.center })_{i}+\beta_{2, t} 1($ year $=t) *$ closeness $(\text { mil.base })_{i}+\varepsilon_{i, t}$

$$
v c_{i, t}=\delta_{i}+\delta_{t}+\theta_{1} \text { mil }_{i, t}+\theta_{2, t} 1(\text { year }=t) * \operatorname{closeness}(\text { mil.base })_{i}+\gamma_{i, t}
$$

The military bases that are used to calculate closeness $(\text { mil base) })_{i}$ are the ones that are currently still open and that could have been selected as DLA disposition centers in 1996. This does not include military hospitals, military training centers, and joint airports. There are 172 military bases that comply with these characteristics, of which, as said before 69 were selected as DLA disposition centers. In the first stage, $1($ year $=t) *$ closeness $(\text { mil.base })_{i}$ controls for the fact that police departments close to a military base are different in many characteristics that may influence their demand for military equipment. Added to this effect, with $e q p_{t} *$ closeness(disp.center $)_{i}, \mathrm{I}$ want to capture that if a police department is close to a military base that is a disposition center, it will obtain more military equipment, especially after 2009. In the second stage, by having $1($ year $=t) *$ closeness $(\text { mil.base })_{i}$ as an included instrument, I control for the fact that police departments close to military bases may have different trends in violent crime with respect to other police departments across the US. Furthermore, with this flexible specification, I let the closeness to a military base have an influence on violent crime that may vary year by year. Because of this, I 
do not impose that the factors that affect police departments close to a military base have the same time structure as the withdrawal of troops from Iraq and Afghanistan.

As described before, there are potentially many ways of combining the information in Figure 2 to create a proper measure of closeness. As a baseline throughout the paper, I define a place to be close to a DLA disposition center if it is located at less than $20 \mathrm{~km}$ (air distance) from one of them. This specific measure of closeness has been chosen as a baseline specification because is the dummy variable that has the strongest predictive power in the first stage. Using a dummy variable for the cross-sectional variation makes it easier to conceptualize the validity of the identification strategy. For example, the "treated" police departments are easily defined as those at less than $20 \mathrm{~km}$ from a disposition center. Furthermore, I can separate the not "treated" police departments in two groups of police departments that are particularly relevant for the analysis. The first is the group of police departments that are less than $20 \mathrm{~km}$ from a military base but at more than $20 \mathrm{Km}$ from a disposition center. Throughout the rest of the paper, I call these police departments "controls". There is also a final group of police departments I call "rest"; these are all the police departments that are more than $20 \mathrm{~km}$ away from a military base (and therefore more than $20 \mathrm{Km}$ far away from a disposition center). In Section 4.4 I show how results are robust to many other definitions of closeness. 


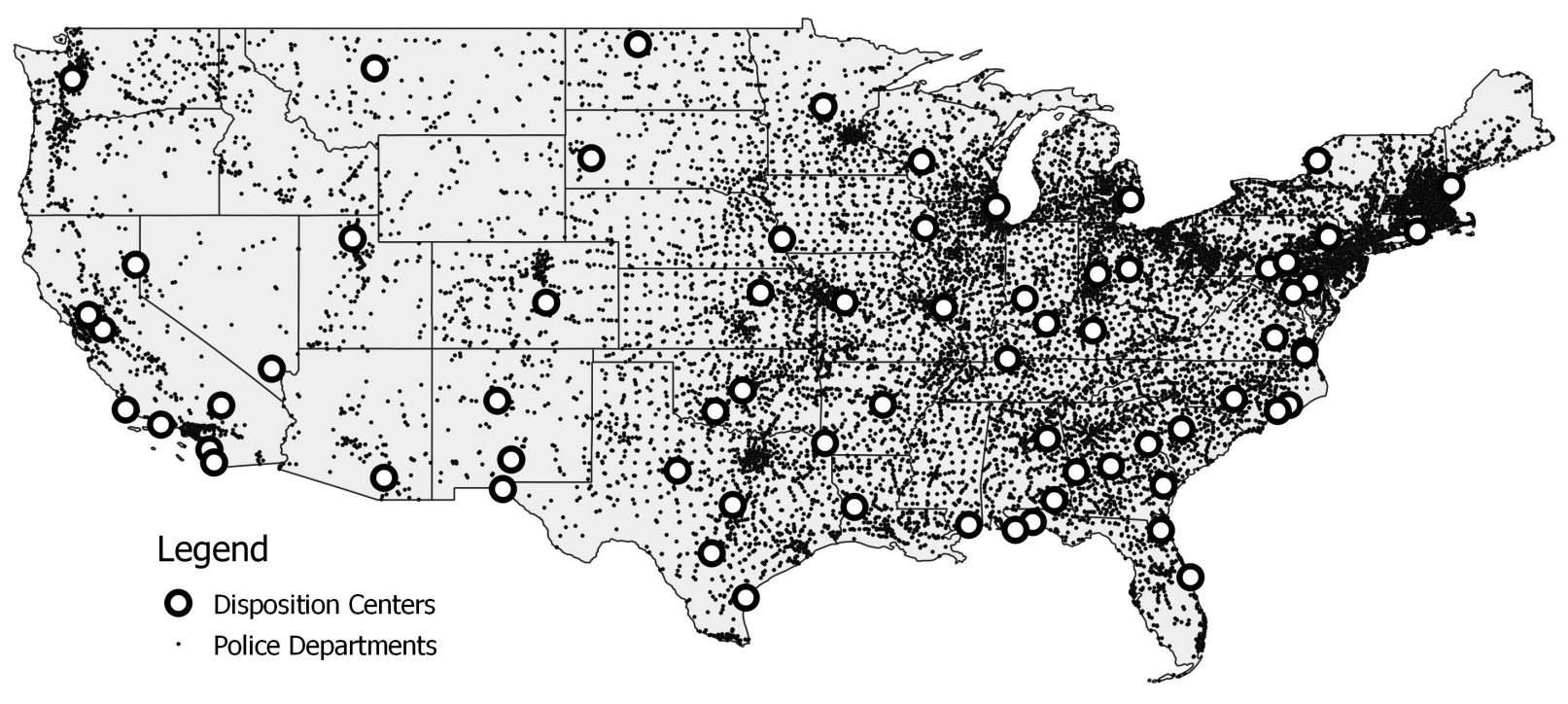

Figure 2: Disposition centers and police departments in the continental US

Given these definitions, the identifying assumption is that changes in violent crime rates between before and after the withdrawals from the wars are not different between police departments treated and control, other than through the military equipment received by these police departments. In Section 4.3 I provide evidence of the plausibility of this identification strategy.

\section{Results}

\subsection{First Stage}

I first provide evidence of the relationship between the distance to the closest disposition center and the militarization of a police department. I do so by estimating the following equation:

$$
m i l_{i, t}=\alpha_{i}+\alpha_{t}+e q p_{t} * f_{1}\left(\text { distance disp.center }{ }_{i}\right)+e q p_{t} * f_{2}\left(\text { distance mil.base }_{i}\right)+\varepsilon_{i, t}
$$

Where $f_{1}($.$) and f_{2}($.$) are fourth order polynomials. Figure 3$ shows the estimated function $f_{1}($.$) .$ First, is important to notice that given that I control for $f_{2}\left(\right.$ distance mil.base $\left.e_{i}\right), f_{1}($.$) should be$ interpreted as the effect on militarization that distance to a disposition center has after discounting the fact that police departments close or far away from a military base may make different 


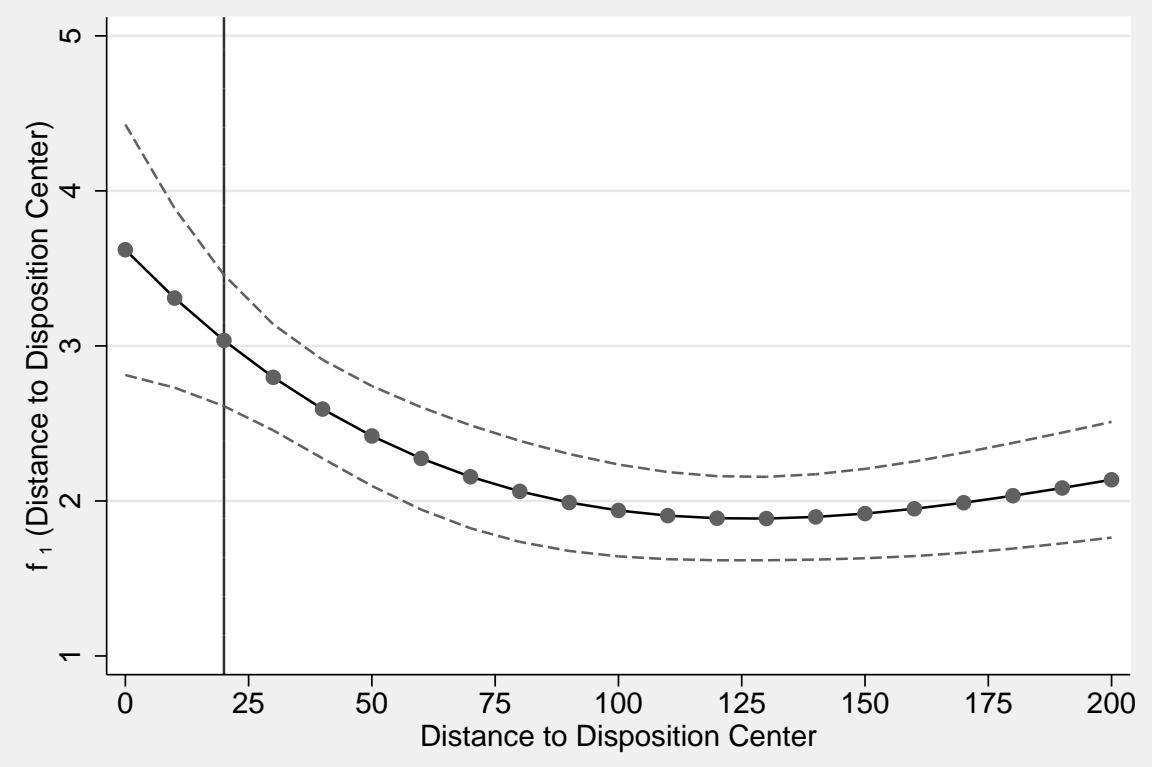

Figure 3: The effect on militarization of the withdrawal from the wars as a function of the distance to a disposition center. $f_{1}($.$) is a fourth order polynomial. The vertical line indicates 20 \mathrm{~km}$.

militarization decisions. The first result is that, indifferently of the distance from a disposition center, militarization has increased when comparing the period before and after 2010. Particularly important for the relevance of the instrument, Figure 3 shows that distance affects militarization negatively. Figure 3 also shows how this negative relationship is not linear. Distance matters a lot in the first few kilometers. After $100 \mathrm{~km}$, distance no longer affects the militarization of a police department. The baseline instrument is a simplification of this non-linear relationship that compares police departments at less than $20 \mathrm{~km}$ (in Figure 3, to the left of the solid vertical line) with police departments farther away than $20 \mathrm{~km}$.

In Figure 4, I directly provide evidence of the relevance of the baseline instrument, by comparing the time-series of the value of the stock of military equipment of treated and control police departments. First of all, Figure 4 shows that from 2010 onward, there is a huge increase in the militarization of police departments. Treated police departments are always more militarized than the control ones, but this difference is only a few cents per capita until 2009. When US troops start withdrawing from the war in Iraq and Afghanistan in late 2009 the difference between these 


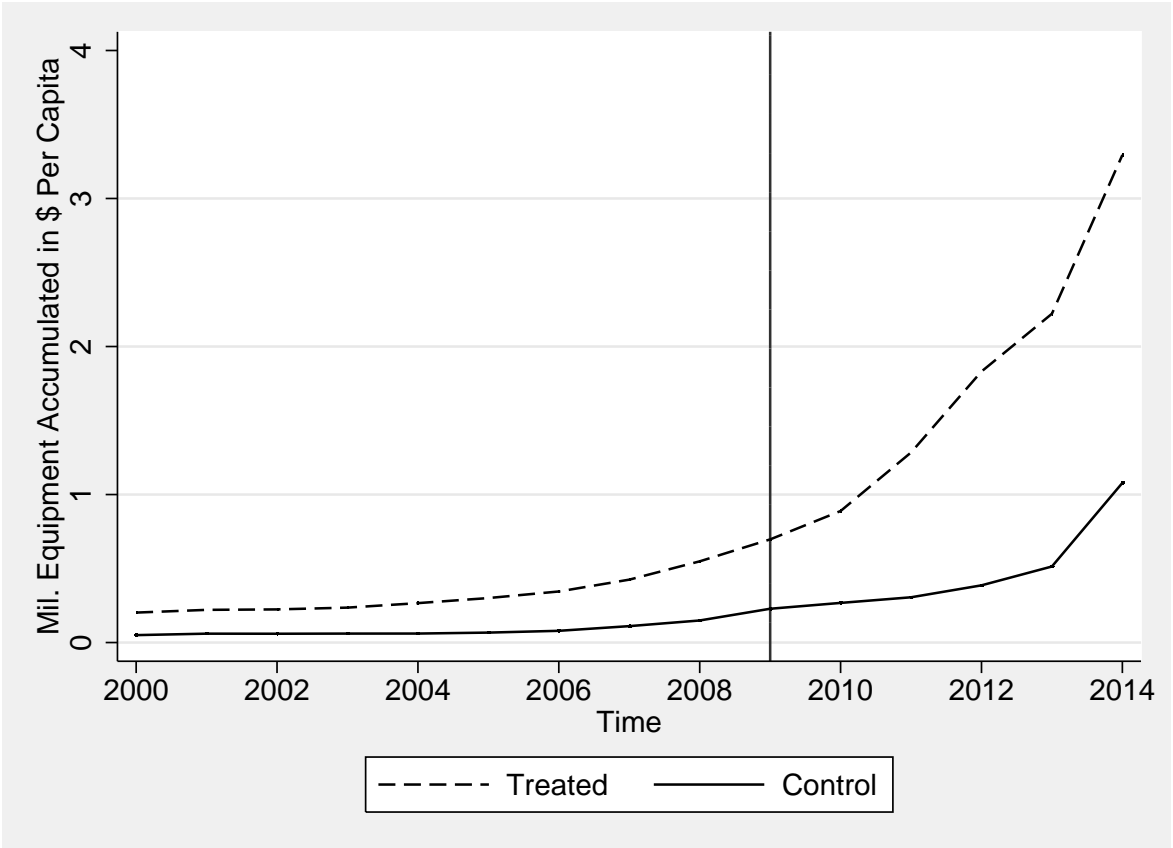

Figure 4: Time series of the stock of military equipment in $\$$ per capita. The dotted line for police departments that are at most at $20 \mathrm{~km}$ for a disposition center (Treated). The solid line for police departments that are at most at $20 \mathrm{~km}$ from a military base that is not a disposition center (Control)

two groups of police departments increases. In 2014, treated police departments have an extra two dollars per capita of military equipment with respect to control police departments ${ }^{16}$

More formally, in Table 11, column (1) reports the estimates for $\beta_{1}$ for the first stage previously described. The regression results are estimated with a sample from 2007 to 2014 . This estimate shows what is already highlighted in Figure 4. Police departments close to disposition centers experience a steeper increase in their level of militarization after 2009. Treated police departments increase militarization per capita by an extra dollar and 54 cents between 2009 and 2014, with respect to control police departments.

\footnotetext{
${ }^{16}$ At first visual inspection of Figure 4 the differential increase in militarization may seem to start before 2009. First, it is important to notice that the parallel trends assumption necessary for identification has to be guaranteed on the outcome of interest and not the regressor. Even though differential trends in militarization are not a sign of concern in Table 2 I formally show that trends in militarization between treated and control police departments were the same before 2009.
} 


\subsection{Baseline Results}

With this identification strategy, I can now estimate the causal effect of the militarization of the police on the violent crime rate. The baseline regression results are shown in Table 1 . The OLS results in columns (2) and (3) show a positive but not statistically significant correlation between militarization and violent crime. These results are consistent with militarization having a negative effect on violent crime but the OLS coefficient are positively biased because of reverse causality. Columns (4) and (5) present the preferred IV specifications. Both show how militarization per capita reduces the violent crime rate. Every dollar per capita in military equipment decreases violent crime by 1.5 per 1,000 inhabitants, or as shown in column (5), by 7.7 percent. Column (6) presents the reduced form estimate: Violent crime in police departments close to a disposition center experienced a drop of an extra 2.4 violent crimes per 1,000 inhabitants.

Table 1: Baseline Results

\begin{tabular}{lcccccc}
\hline & $(1)$ & $(2)$ & $(3)$ & $(4)$ & $(5)$ & $(6)$ \\
& Mil. per Capita & Violent Cr. & Violent Cr. & Violent Cr. & $\ln$ (Violent Cr.) & Violent Cr. \\
\hline Eqp. X 1(disp<20Km) & $1.543^{* * *}$ & & & & & $-2.388^{* * * *}$ \\
& $(0.439)$ & & & & & $(0.434)$ \\
Militarization per Capita & & & & & & \\
& & 0.00110 & 0.000414 & $-1.547 * * *$ & $-0.0766^{* * *}$ & \\
\hline Observations & & $(0.00185)$ & $(0.00181)$ & $(0.511)$ & $(0.0252)$ & \\
Year FE & 89994 & 89994 & 89994 & 89994 & 89994 & 89994 \\
Police Dep. FE & Yes & Yes & Yes & Yes & Yes & Yes \\
1(Milbase<20Km)* Year & Yes & Yes & Yes & Yes & Yes & Yes \\
Estimation & Yes & No & Yes & Yes & Yes & Yes \\
F-stat & OLS & OLS & OLS & IV & IV & OLS \\
\hline
\end{tabular}

Note: In column (1) the dependent variable is the US\$ value of the militarization per capita while in column (5) is the natural log of the violent crime rate. In all the other columns the dependent variable is the violent crime rate per 1,000 inhabitants. The sample includes all police departments yearly data from 2007 to 2014 . Column (1) presents the first stage. Columns (2) and (3) report the OLS estimates of militarization per capita on violent crime rate. Columns (4) and (5) report the IV second stage estimates. Finally Column (6) reports the reduced form effect of the treatment status. In all columns clustered standard errors at the Commuting Zone*Year level are reported in brackets. Regressions are weighted by population. * $p$-value $<0.10$, ** $p$-value $<0.05$, *** $p$-value $<0.01$

For interpreting the marginal effects found in Table 1, notice that in 2014, the average militarization of a police department in the US was of $\$ 3.25$ per capita. This means that the average effect of militarization in 2014 is to reduce violent crime by 5 crimes per 1,000 inhabitants. This 
is the difference between one of the safest big cities in the US, New York that in 2014 had only 6 violent crimes per 1,000 inhabitants and a big city with a median violent crime rate like Miami with 10.9 crimes per 1,000 inhabitants or Los Angeles with 11.5 per 1,000 inhabitants.

Another way of interpreting the magnitude of these results is noticing that $\$ 3.25$ per capita would be enough for a police department of 100,000 inhabitants to afford a 10 man fully armed military squad ${ }^{17}$ A police department of these dimensions would have around 3.34 violent crimes a day in 2014. The estimates of Table 1 imply that without militarization, the daily violent crimes would be around 4.76 or 4.49 , using the linear or the logarithmic estimation, respectively. As shown in this example, the militarization of the police has a substantial effect on the reduction of violent crime.

One important consideration to make when exploring how generalizable the baseline results are is to take into account that in an instrumental variable setting the estimated parameter should be interpreted as a local average treatment effect on the complier population. The compliers of the instruments are police departments that decide to militarize only if they are close to a disposition center. In other words, for the compliers costs related to the distance to a disposition center heavily reduce militarization. In case there are heterogeneous effects of militarization on violent crime for different police departments the results presented in Table 1 may not be generalizable to the whole population. In Section 4.4 I explore how the results change depending on the definition of closeness to a disposition center. This exercise can help us understand how representative the results are to the overall population of police departments in the US as each definition of closeness will have a different complier population and potentially a different LATE.

Furthermore, I explore how the effects reported in Table 1 may vary with the size of the police department. This is particularly important as the size of the police department may also affect the likelihood that a police department is in the complier population. For example, the largest police

\footnotetext{
${ }^{17}$ Expenses to fully equip a military squad highly depend on the type and quality of items. The example of the 10 officers fully armed squad used includes one armored truck, one explosive disposal equipment, two night-vision goggles and two thermal sights. Added to this are a set of 10 assault rifles, sights and body armor. Depending on the quality of these items it may cost around $\$ 325,000$ of 3.25 per capita for this hypothetical police department of 100,000 population.
} 
departments may have enough resources to cover the transportation costs of military equipment because of these militarization decisions may not be affected by distance to the disposition center (always-takers). The smallest police departments may not have any budget for new equipment, so the militarization decision of these departments is also not influenced by distance as they never get militarized (never-takers). Is plausible to think that the rest of the police departments are the compliers to the instrument and get militarized more when close to a disposition center. In the Appendix I explore how the size of the police department influences the effect of militarization on crime. In line with the arguments in Balko (2014) the biggest police departments are better able to use military equipment because they are the only ones that can afford to have a police unit that specializes in the use of military equipment.

Finally, I compare these results with the effects of militarization on violent crime estimated in Bove and Gavrilova (2017) and Harris et al. (2017). In the Appendix I describe more carefully the comparison. The estimated effect in Column (4) of Table 1 is 26 times larger than the largest and statistically significant estimated effect of militarization on the violent crime rate found in the literature. I then follow the preferred specification in Bove and Gavrilova (2017) and Harris et al. (2017) where they study the effect of a percentage increases in militarization on violent crime. In this case, the estimated effect using the identification strategy proposed in this paper are 17 times larger than the biggest effect found in the literature.

\subsection{Plausibility of the Identification Strategy}

The previous results hinge on the identifying assumption that changes in violent crime rates before and after 2010 are not different between treated and control police departments other than through the military equipment received by these police departments. Another way interpreting this assumption is that in 1996, when the 1033 Program was created the selection made as to which military bases would be used as disposition centers was not biased towards military bases located in areas that after 2009 will have a higher drop in violent crime.

It seems reasonable to assume that the selection of disposition centers was not actively biased 
towards military bases located in areas that will experience a disproportionately high drop in violent crime 14 years later. First, it is not feasible to predict violent crime trends so many years ahead. This is especially true in the US at that time, when crime has moved spatially in the last two decades because of the intensification in the war of drugs, the rise of opioids, and the decline of some industrial cities. Furthermore, as Harris et al. (2017) points out, "the 1033 Program is a non-trivial, but certainly non-dominant part of DLA's overall cost minimization problem". Still, it could be the case that the military bases selected as disposition centers were selected because of some other reason that ended up being relevant in causing different trends in crime after 2009.

To explore this, in Table 2, I provide evidence that treated and control police departments are similar in many predetermined observable variables that are potentially related to crime. Table 2 shows that treated and control police departments do not differ in any substantial way. Furthermore, it is also important to notice how treated police departments and those that are not close to a disposition center (denominated with "Not Treated" in the table) are instead, substantially different. These police departments tend to be smaller in population, larger in size and have lower crime rates with respect to the treated ones.

I then explore if the trends of these variables are similar between treated and control police departments. To do so, in Table 3, I report the trends of all the time-varying police department observables studied in Table 2, The trends of all these variables are similar between treated and control police department. Importantly, violent crime trends between treated and control police departments do not have statistically different trends. These similarities are encouraging because it means that, there were no observable differences between these two groups before 2009 and any change in trends after that could be plausibly attributed to the 1033 Program.

As final evidence of the validity of the identification strategy, I perform an event study analysis. The intention here is to test the intuition displayed in Table 3 formally by comparing, in a flexible way, if there are any differences between treated and control police departments before 2009 and exploring if these police departments started diverging after the start of the withdrawal from the Iraqi and Afghan wars. To check this, I estimate the following regression: 
Table 2: Comparing Levels of Predetermined Observables

\begin{tabular}{lccccc}
\hline \hline Variable & Treated & $\begin{array}{c}\text { Control } \\
(\mathbf{1})\end{array}$ & $\begin{array}{c}\text { Not Treated } \\
\mathbf{( 3 )}\end{array}$ & $\begin{array}{c}\text { Difference } \\
(\mathbf{1}) \mathbf{- ( 2 )}\end{array}$ & $\begin{array}{c}\text { Difference } \\
\mathbf{( 1 )}-\mathbf{( 3 )}\end{array}$ \\
\hline Sheriff Department & 0.15 & 0.09 & 0.30 & 0.06 & $-0.15^{\star \star \star}$ \\
Municipal Level & 0.74 & 0.76 & 0.58 & -0.02 & $0.16^{\star \star \star}$ \\
Area & 319.38 & 230.27 & 550.90 & $89.11^{\star}$ & $-231.53^{\star \star}$ \\
Employees per Crime & 0.06 & 0.12 & 0.10 & -0.06 & $-0.04^{\star \star \star}$ \\
Violent Crime Rate & 18.85 & 14.72 & 13.61 & 4.14 & $5.24^{\star \star \star}$ \\
Property Crime Rate & 37.70 & 31.09 & 29.58 & 6.61 & $8.12^{\star \star \star}$ \\
Population & 63067 & 63466 & 23590 & -399 & $39477^{\star \star \star}$ \\
\hline \% Male & 49.29 & 48.61 & 49.04 & 0.68 & 0.25 \\
\% Latino & 15.99 & 16.35 & 12.57 & -0.35 & 3.42 \\
\% Mexican & 10.86 & 5.09 & 7.26 & 5.76 & 3.59 \\
\% Black & 14.12 & 21.01 & 12.15 & $-6.89^{\star}$ & 1.97 \\
Rural County & 0.03 & 0.02 & 0.18 & 0.01 & $-0.15^{\star \star \star}$ \\
Peak Criminal Age (Male 15-24) & 14.81 & 13.99 & 13.86 & 0.82 & $0.95^{\star \star \star}$ \\
Unemployment Rate & 3.81 & 4.22 & 4.07 & -0.40 & -0.26 \\
\% Less than High-School & 17.39 & 18.67 & 19.76 & -1.27 & $-2.37^{\star \star}$ \\
Republican Governor (2000) & 0.74 & 0.65 & 0.61 & 0.10 & $0.14^{\star}$ \\
Republican Governor (2004) & 0.65 & 0.70 & 0.63 & -0.06 & 0.01 \\
Republican Governor (2008) & 0.45 & 0.35 & 0.45 & 0.10 & -0.01 \\
Governor Election (2008-2009) & 0.16 & 0.19 & 0.18 & -0.03 & -0.02 \\
Governor Election (2013-2014) & 0.90 & 0.86 & 0.84 & 0.04 & 0.06 \\
\hline
\end{tabular}

Note: This table shows some predetermined observables for police departments less than $20 \mathrm{~km}$ from a disposition center (Treated) [N=375], police departments less than $20 \mathrm{~km}$ from a military base that is not a disposition center (Control) $[\mathrm{N}=554]$ and police departments more than $20 \mathrm{~km}$ from a disposition center (Not Treated) [ $\mathrm{N}=11832]$. The last two columns tests it tests if there are difference between treated and control police departments and between treated and not treated police departments. $\star 10 \% \star \star 5 \% \star \star \star 1 \%$. The first 7 variables (above the horizontal line) are at the police department level in the year 2009. The other variables are at the county level. Demographic variables are from the 2000 Census. 
Table 3: Comparing Predetermined Trends

\begin{tabular}{lccccc}
\hline \hline Variable & $\begin{array}{c}\text { Treated } \\
(\mathbf{1})\end{array}$ & $\begin{array}{c}\text { Control } \\
(\mathbf{2})\end{array}$ & $\begin{array}{c}\text { Not Treated } \\
\mathbf{( 3 )}\end{array}$ & $\begin{array}{c}\text { Difference } \\
(\mathbf{1})-(\mathbf{2})\end{array}$ & $\begin{array}{c}\text { Difference } \\
(\mathbf{1})-(\mathbf{3})\end{array}$ \\
\hline Militarization per Capita & 0.175 & 0.108 & 0.146 & 0.066 & 0.029 \\
Employees per Crime & 0.004 & 0.003 & 0.007 & 0.001 & $-0.004^{\star}$ \\
Violent Crime & -1.019 & -1.535 & -0.835 & 0.516 & -0.184 \\
Property Crime & -3.247 & -3.734 & -2.470 & 0.487 & -0.776 \\
Population & 1727.844 & 1943.629 & 401.564 & -215.785 & $1326.280^{\star \star \star}$ \\
\hline
\end{tabular}

Note: This table shows the change of various outcome variables between 2007 and 2009 for police departments less than $20 \mathrm{~km}$ from a disposition center (Treated) [ $\mathrm{N}=375]$, police departments less than $20 \mathrm{~km}$ from a military base that is not a disposition center (Control) $[\mathrm{N}=554]$ and police departments at more than $20 \mathrm{~km}$ from a disposition center (Not Treated) $[\mathrm{N}=11832]$. The last two columns tests it tests if these changes are different between treated and control police departments and between treated and not treated police departments. $\star$ $10 \% \star \star 5 \% \star \star \star 1 \%$

$v c_{i, t}=\sigma_{i}+\sigma_{t}+\sigma_{1, t} 1($ year $=t) * 1(\text { disp.center }<20 \mathrm{~km})_{i}+\sigma_{2, t} 1($ year $=t) * 1(\text { mil.base }<20 \mathrm{~km})_{i}+\varepsilon_{i, t}$

The sample includes all police departments' yearly data from 2001 to 2014 . The comparison year is 2009, the last year before massive amounts of military equipment arrived in the US. The estimates of $\sigma_{1, t}$ are shown in Figure 5. Before 2010, there was no statistical difference between places close to and far away from disposition centers. As soon as military equipment returned to the US violent crime around disposition centers started decreasing faster than in any other areas. This timing is encouraging evidence of the validity of the identification assumption because it not only shows parallel trends in violent crime but that the start of separation between treated and control police departments coincides with the huge influx of military equipment into the US.

\subsection{Robustness}

In the first panel of Table 4. I show how the first stage is robust to different definitions of the closeness to a disposition center. Column (1) shows the baseline specification. In Column (2), I expand the radius to include police departments less than $40 \mathrm{~km}$ from the disposition center. These estimates show that these police departments receive 89 cents more per capita between 2009 and 2014. In Column (3), I include the distance to a disposition center linearly. The estimates imply 


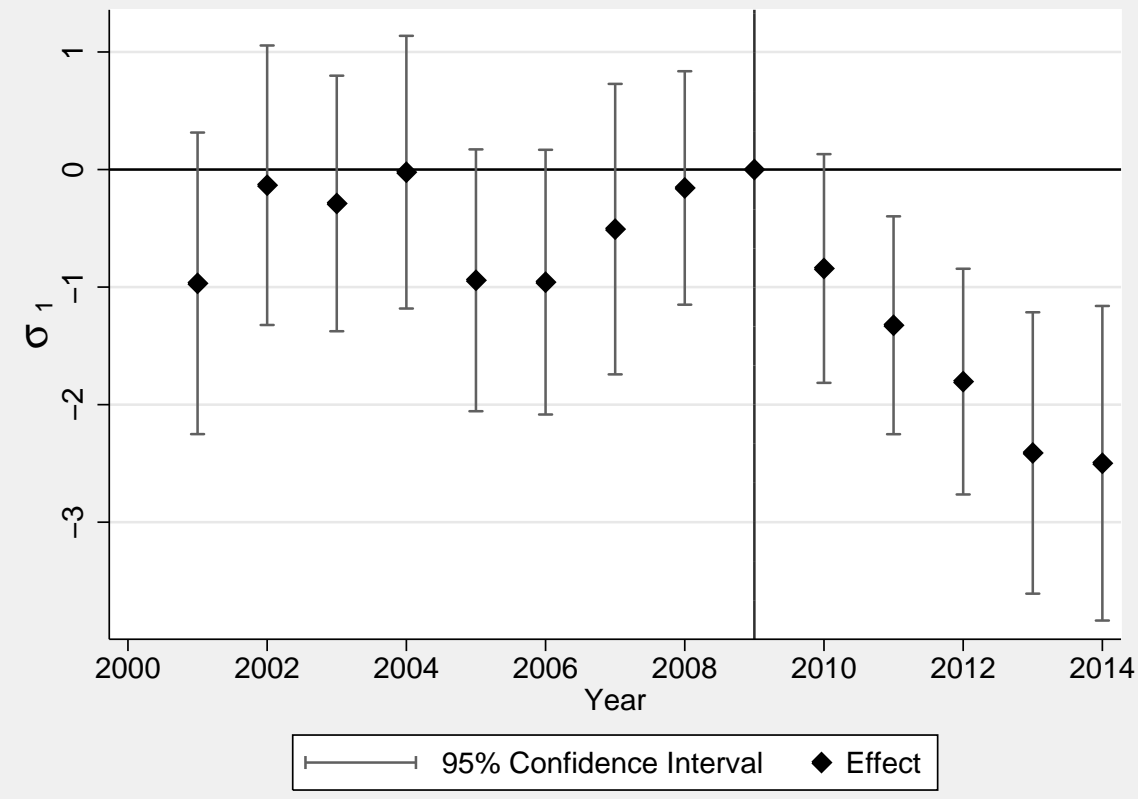

Figure 5: $\sigma_{1, t}$ is the effect in year $t$ of being close to a disposition center on the violent crime rate (2009 as comparison year)

that militarization decreases by 5 cents every $10 \mathrm{Km}$ of distance from a disposition center. Given the evidence of the non-linearities that distance to a disposition center has on militarization, shown in Figure 3 in Column (4) I include the distance to the closest disposition center logarithmically. The estimate shows that for every doubling of the distance to the disposition center, the amount of militarization decreases by 48 cents per capita. In Columns (5) and (6), uses the number of disposition centers in a certain radius around a police department. The idea behind this instrument the cost of getting a particular item decreases with the number of disposition centers a police department has close access to. This is because, at a specific moment in time, some items may be available only at some disposition centers. When a police department has many disposition centers nearby, it is more likely it will be able to get exactly the item it wants. Indeed, the results show how every additional disposition center in either a 50 or a $100 \mathrm{~km}$ radius increases the amount of military equipment a police department gets by respectively 79 cents and 50 cents per capita.

In the second panel of Table 4, I show that the second stage results are robust to the choice of the instrument. In all the specifications, the effect of militarization per capita on violent crime is 
Table 4: Robustness to Different Measures of Closeness to Disposition Centers

\begin{tabular}{lcccccc}
\hline & $(1)$ & $(2)$ & $(3)$ & $(4)$ & $(5)$ & $(6)$ \\
& $<20 \mathrm{Km}$ & $<40 \mathrm{Km}$ & Dist & $\ln$ (Dist.) & Num. 50Km & Num. 100Km \\
\hline \multicolumn{5}{c}{$\beta_{1}$} & \multicolumn{5}{c}{ First Stage: Militarization } \\
& $1.543^{\star \star \star}$ & $0.889^{\star \star \star}$ & $-0.005^{\star \star \star}$ & $-0.477^{\star \star \star}$ & $0.787^{\star \star \star}$ & $0.500^{\star \star \star}$ \\
& $(0.439)$ & $(0.310)$ & $(0.002)$ & $(0.116)$ & $(0.268)$ & $(0.180)$ \\
$\theta_{1}$ & & \multicolumn{5}{c}{ Second Stage: Violent Crime } \\
& $-1.547^{\star \star \star}$ & $-1.579^{\star \star \star}$ & $-0.784^{\star \star}$ & $-1.205^{\star \star \star}$ & $-1.322^{\star \star}$ & $-0.998^{\star \star}$ \\
\hline Observations & $(0.511)$ & $(0.584)$ & $(0.317)$ & $(0.373)$ & $(0.520)$ & $(0.417)$ \\
F-stat & 89994 & 89994 & 89994 & 89994 & 89994 & 89994 \\
\hline
\end{tabular}

Note: The table reports the estimates of the first stage $\beta_{1}$ and second stage $\theta_{1}$ for different measures of closeness. Clustered standard errors at the Commuting Zone * Year level (in brackets). The sample includes all police departments yearly data from 2007 to 2014. In the first 2 columns a police department is defined as close if situated at less than $20 \mathrm{~km}$, for column 1 , and $40 \mathrm{~km}$, for column 2 , from a disposition center. In column 3 I use the distance in $\mathrm{km}$ and in column 4 the logarithmic distance in $\mathrm{km}$ from the closest disposition centers. In column 5 and $6 \mathrm{I}$ use the number of disposition centers in a radius of $50 \mathrm{~km}$ and $100 \mathrm{~km}$ as a measure of closeness. All regressions include police departments fixed effects, year fixed effects and $y e a r_{t} *$ closeness (militarybase) and are weighted by population. ${ }^{*} p$-value $<0.10$, ** p-value $<0.05$, *** p-value $<0.01$ 
negative. The baseline specification has one of the highest estimated effects. The effects vary from -0.78 to a maximum of -1.58 .

I then show how results are robust to estimation in different subsamples, changing the definitions of the variables of interest, changing the weighting methodology and using flexible functions of distances for constructing the instrument. Furthermore, I study the effects of militarization on different types of violent crimes. I also perform a permutation exercise where I randomly assign military bases as disposition centers for the 1033 Program. I show that the effects observed on violent crime are confined to police departments close to disposition centers and not all military bases. For robustness, I also include census division, state or commuting zone trends. Finally, I show that when a police department gets militarized, the number of police officers and employees does not change. Because of this result, we can interpret the effect on the reduction of violent crime to be directly due to the military equipment and not driven by a change in personnel. All these robustness checks can be found in the Appendix.

\section{Mechanisms}

\subsection{Displacement Effects}

In line with the assumption that criminals are rational actors, the location of criminal activity may react to the militarization of a police department by criminals moving their criminal activities to neighboring areas. It is crucial to understand the presence and size of these displacement effects. First of all, the effectiveness of hot spot policing, which mandates concentrated policing efforts in places where crime is pervasive, is conditional on how important these displacement effects are. Furthermore, more specifically to the 1033 Program, this type of displacement effect may induce police to overmilitarization. This is because militarization decisions are made at the police department level while, if the displacement effect exists, it is suffered by neighboring police departments. Because of this negative externality not being internalized by the police department when making the militarization decision, we would observe that, in equilibrium, police departments are overmil- 
itarized. Finally, by not controlling for the potential spillover that neighboring police departments one would underestimate the direct effect that militarization has on criminal activity.

In this section I investigate the presence of displacement effects with the following econometric framework:

$$
v c_{i, t}=\alpha_{i}+\alpha_{t}+\beta_{1} m_{i l} l_{i, t}+\beta_{2} W_{i} \mathbf{m i l}_{\mathbf{t}}+\beta X_{i, t}+\varepsilon_{i, t}
$$

as before $i$ identifies the police department, $t$ the year. $W_{i}$ is a weighting matrix that selects the neighbors of police department $i$. mil $\mathbf{l}_{\mathbf{t}}$ is a vector of militarization per capita of all police departments at time $t$. Throughout all the analysis of the displacement effects I consider the spillovers to be confined by the commuting zone where the police department is located. $W_{i} \mathbf{m i l}_{\mathbf{t}}$ is then the average militarization in the commuting zone of police department $i$. Commuting zones are groups of counties with strong labor market ties. Workers often commute from and to work inside this area. It is plausible to assume that also workers in the illegal sector have small costs in moving their illegal activities inside a commuting zone. In average each commuting zone has 60 police departments. As in the previous section $\beta_{1}$ identifies the effect of the militarization of the police department $i$ on the violent crime committed inside its jurisdiction. $\beta_{2}$ instead is the effect that the average militarization in police department $i$ commuting zone has on the violent crime committed in police department $i$ jurisdiction. The rational criminal theory would predict a positive $\beta_{2}$ because some criminals would displace their activities in neighboring areas once the jurisdiction they were operating in becomes more militarized.

The analysis of displacement effects adds another potential endogeneity problem. In equation (6) $W_{i} \mathbf{m i l}_{\mathbf{t}}$ can also be endogenous because of reverse causality and omitted variable bias even after controlling for the endogeneity of $m i l_{i, t}$. First, neighboring police departments may decide to increase their militarization because of a general trend in violence in the commuting zone, leading to a reverse causality problem. Second, there are potentially unobservables that are common to a commuting zone that affect changes in the militarization of a police department and violent crime.

In order to solve the potential endogeneity problem I follow Wooldridge (2000) by first exogenously predicting militarization using the first stage in equation (3a). I then use as instruments for 
the endogenous variables $m_{i, t}$ and $W_{i} \mathbf{m i l}_{\mathbf{t}}$ in equation (6) the predicted militarization of police department $i$ and the average predicted militarization in the commuting zone of police department $i$. In the Appendix, I show that results are robust to a series of alternative specifications: First, I use the average distance to a 1033 disposition center in a commuting zone as an instrument. Second, I control for $W_{i} \mathbf{m i l}_{\mathbf{t}}$ and only instrument for $m_{i} l_{i, t}$. I then follow a control function approach. Finally, I estimate equation (6) using different functions for the closeness to military bases or disposition center. In all specifications, I control for closeness to a military base multiplied by year fixed effects.

To understand where the variation that identifies $\beta_{1}$ and $\beta_{2}$ comes from imagine a commuting zone where a disposition center is located at the edge of the commuting zone. In this type of commuting zones some police departments are far away from the disposition centers and will not get particularly militarized. At the same time, some other police departments in the same commuting zone will be close to the disposition center and get highly militarized. The police departments that are far away from the disposition center will suffer from the spillovers of the militarization of their neighbors while not enjoying the crime-reducing direct effects of their own militarization on violent crime in their jurisdiction. The police departments close to the disposition center instead will be affected by both the effects. This variation inside a commuting zone allows me to identify these two effects separately.

Table 5 show the instrumental variable estimates of Equation (6). As shown in column (2) and (4) the displacement effects are present and are relatively important. For each dollar per capita spent in a police department commuting zone, the violent crime rate increases by 0.39 per 1,000 inhabitants. In Column (4) where the outcome of interest is the logarithm of the violent crime rate, we observe an increase in violent crime of 1.9 percent; this amounts to around one fourth of the direct effect that the militarization of the police has on violent crime.

For interpreting the marginal effects found in Table 5, I return to the example of a police department of 100,000 inhabitants that can afford a 10 man fully armed military squad. As discussed in the previous chapter, a police department of this dimension would have around 3.34 violent crimes 
Table 5: Displacement Effects

\begin{tabular}{lcccc}
\hline & $(1)$ & $(2)$ & $(3)$ & $(4)$ \\
& Violent Cr. & Violent Cr. & $\ln ($ Violent Cr.) & $\ln ($ Violent Cr.) \\
\hline Militarization per Capita & $-1.547^{* * *}$ & $-1.646^{* * *}$ & $-0.0766^{* * *}$ & $-0.0814^{* * *}$ \\
& $(0.511)$ & $(0.554)$ & $(0.0252)$ & $(0.0276)$ \\
CZ Militarization per Capita & & $0.393^{* * *}$ & & $0.0190^{* * *}$ \\
& & $(0.128)$ & & $(0.00694)$ \\
\hline Observations & 89945 & 89945 & 89945 & 89945 \\
F-stat & 39.82 & 18.44 & 39.82 & 18.44 \\
P-value Underidentification & 0 & 0 & 0 & 0 \\
\hline
\end{tabular}

Note: In columns (1) and (2) the dependent variable is the violent crime rate per 1,000 inhabitants, in columns (3) and (4) the dependent variable is the log of the violent crime rate. The sample includes all police departments yearly data from 2007 to 2014. The table reports IV estimates of $\beta_{1}, \beta_{2}$ and clustered standard errors at the Commuting Zone * Year level in brackets. All regressions include police department fixed effects, year fixed effects and year $* 1$ (militarybase $<20 \mathrm{~km})$. Regressions are weighted by population. * p-value $<0.10, * *$-value $<0.05$, *** p-value $<0.01$

a day in 2014. The estimates of Table 5 imply that without militarization the daily crimes would be around 4.26 and 4, using a linear or logarithmic estimation, respectively. These results show how even if the effect of militarization on violent crime is still sizable, the effects are as not as large as when the estimation was carried without taking into account displacement effects.

Another way of quantifying the results is to look at the total effect of the 1033 Program since it was implemented in 1997. The estimates shown in Column (4) of Table 5 predict that this program has prevented 2 million violent crimes since its inception. Most of these prevented violent crimes are in recent years. Trying to put a monetary value on the prevented costs to society produced by the reduction in crime of the 1033 Program is not an easy task. First of all, the costs produced by violent crime depends on the type of crime. Second, even when a crime is known different methods disagree on cost produced by each crime. An excellent review of the literature is given by McCollister, French and Fang (2010). Using less costly violent crime (that is $\$ 42310$ for a robbery) as the most conservative estimate the 1033 Program has prevented $\$ 86$ Billion US in costs. 


\subsection{Incapacitation or Deterrence}

The mechanisms by which more policing may lead to a reduction in crime can be broadly divided into two categories: incapacitation or deterrence. The first effect is just a mechanical one, where more policing leads to more arrests, fewer criminals circulating on the streets and consequently, fewer crimes are committed. Deterrence instead arises when rational criminals observe the change in policing and decide as a response to change their criminal activity. From a policymaker perspective, it is important to understand which of the two mechanisms causes the drop in crimes. If the main mechanism at play is incapacitation it would create two additional costs for the society: first, incarceration is expensive and violent crimes especially require long incarceration periods and second, the productive possibilities of an incarcerated individual are diminished (both during and after the incarceration). Deterrence instead is much more desirable, because it does not involve any cost to the judicial system and potentially moves economic activities out of the illegal sector.

Table 6: Arrests

\begin{tabular}{lccccc}
\hline & $(1)$ & $(2)$ & $(3)$ & $(4)$ & $(5)$ \\
& OLS FE1 & OLS FE1 & IV & LOG IV & RF \\
\hline Militarization per Capita & 0.000548 & 0.000115 & $-0.886^{* *}$ & $-0.109^{*}$ & \\
& $(0.00152)$ & $(0.00135)$ & $(0.449)$ & $(0.0556)$ & \\
Eqp. X 1(disp<20Km) & & & & & \\
& & & & & $-0.973 * * *$ \\
Observations & 86914 & 86914 & 86914 & 84334 & 86914 \\
Year FE & Yes & Yes & Yes & Yes & Yes \\
Police Dep. FE & Yes & Yes & Yes & Yes & Yes \\
1(Milbase<20Km)* Year & No & Yes & Yes & Yes & Yes \\
F-stat & & & 19.66 & 19.06 & \\
\hline
\end{tabular}

Note: In column (2) the dependent variable is the log of the arrests due to violent crimes per 1,000 inhabitants. In all the other columns the dependent variable is the number of arrests due to violent crimes per 1,000 inhabitants. The sample includes all police departments yearly data from 2007 to 2014. In all columns clustered standard errors at the Commuting Zone * Year level are reported in brackets. Regressions are weighted by population. * p-value<0.10, $* *$ p-value $<0.05, * * *$ p-value $<0.01$ 
For detecting which mechanism is at play, it is important to notice that, if the effect is entirely due to incapacitation, arrests should increase due to the militarization of the police. Instead, if the mechanism is deterrence, we should observe a decrease in arrests after a police department is militarized. To investigate which mechanism generated the decrease in violent crimes, I look at the effects of the militarization of the police on arrests of violent criminals, as shown in Table 6. The results indicate that militarization had a negative effect on arrests. Every dollar per capita in military equipment decreases arrests of violent crime by 0.89 per 1,000 inhabitants or by 10.9 percent. Taking into account that half of the violent crimes end up cleared by an arrest these results are around half the size of the ones estimated for the violent crime committed. The lower precision of the estimates in Table 6 may indicate that militarization has a heterogeneous effect on arrests. With these results I can tentatively conclude that deterrence is an important contributor to the decrease in violent crime caused by militarization.

\section{Conclusion}

This paper uses new data at the police department level to study the causal effect of the militarization of the police on violent crime. I first show that previous estimates may be contaminated by unobservables that are correlated with militarization and violent crime. I then propose a new identification strategy to solve this issue with estimated effects that are 20 times larger than previously estimated. Results suggest that it does so by deterring criminal activity and by displacing crime to neighboring areas. This evidence is in line with a model with a rational criminal that observe the level of militarization of the police and decide where and how much crime to commit.

These results also inform a heated policy debate that started after the unrests of Ferguson, Missouri in 2014. A congressional investigation was set up in January 2015 leading to a reform of the 1033 Program that reduced the militarization of the police. After five police officers were killed in Dallas in July 2016, another change of the program was under discussion in the Congress to

reverse the reform of January 2015. In August 2017, President Trump issued an executive order 
restoring the full powers of the 1033 Program. This paper provides some important insights for guiding the policymakers' discussion. While militarization has a crime-reducing effect the highly decentralized nature of the program leads to an overmilitarization of the US police. This is the result of police departments not taking into account the externalities they impose on neighboring areas when acquiring new military equipment. Any policy that wants to deal with the overmilitarization of the police will have to take into account the existence of these spillovers. More generally geographical spillover should be taken into account when designing law enforcement policies. 


\section{References}

American Civil Liberties Union. 2014. "The Excessive Militarization of American Policing." June.

Anderson, D Mark, and Daniel I Rees. 2015. “Deployments , Combat Exposure , and Crime.” The Journal of Law \& Economics, 58(1).

Balko, Radley. 2014. Rise of the Warrior Cop: The Militarization of America's Police Forces. PublicAffairs.

Becker, Gary. 1968. “Crime and Punishment: An Economic Approach.” Journal of Political Economy, , (76): 175-209.

Blanes i Vidal, Jordi, and Tom Kirchmaier. 2018. "The Effect of Police Response Time on Crime Clearance Rates.” The Review of Economic Studies, 85: 855-891.

Bove, Vincenzo, and Evelina Gavrilova. 2017. "Police officer on the frontline or a soldier? The effect of police militarization on crime." American Economic Journal: Economic Policy, 9(3): $1-18$.

Carriere, Kevin R., and William Encinosa. 2017. "The Risks of Operational Militarization: Increased Conflict Against Militarized Police." Peace Economics, Peace Science and Public Policy, 23(3).

Cesur, Resul, and Joseph Sabia. 2016. "When War Comes Home: The Effect Of Combat Sevice On Domestic Violence." The Review of Economic and Statistics, 48(2).

Chalfin, Aaron, and Justin Mccrary. 2017. "Criminal Deterrence : A Review of the Literature.” Journal of Economic Literature, 55(1).

Coyne, Christopher J, and Abigail R. Hall-Blanco. 2016. "Foreign Intervention, Police Militarization, and the Impact on Minority Groups.” Peace Review, 28: 165-170. 
Delehanty, Casey, Jack Mewhirter, Ryan Welch, and Jason Wilks. 2017. "Militarization and police violence: The case of the 1033 program.” Research \& Politics, 4(2): 205316801771288.

Di Tella, Rafael, and Ernesto Schargrodsky. 2004. "Do police reduce crime? Estimates using the allocation of police forces after a terrorist attack." American Economic Review, 94(1): 115-133.

Draca, Mirko, Stephen Machin, and Robert Witt. 2011. "Panic on the streets of London: Police, crime, and the july 2005 terror attacks.” American Economic Review, 101(5): 2157-2181.

Evans, William N., and Emily G. Owens. 2007. "COPS and crime.” Journal of Public Economics, 91(1-2): 181-201.

Galiani, Sebastian, Martín A. Rossi, and Ernesto Schargrodsky. 2011. "Conscription and Crime: Evidence from the Argentine draft lottery." American Economic Journal: Applied Economics, 3(2): 119-136.

Harris, Matthew C., Jinseong Park, Donald J. Bruce, and Matthew N. Murray. 2017. "Peacekeeping force: Effects of providing tactical equipment to local law enforcement." American Economic Journal: Economic Policy, 9(3): 291-313.

Kraska, Peter. 2007. “Militarization and Policing - Its Relevance to 21st Century Police.” Policing, $1(4)$.

Lawson, Edward. 2018. "Police Militarization and the Use of Lethal Force." Political Research Quarterly.

Levitt, Steven. 1997. "Do electoral cycles in police hiring really help us estimate the effect of police on crime?" The American Economic Review, 87(3): 270-290.

Machin, Stephen, and Olivier Marie. 2011. "Crime and police resources: The street crime initiative." Journal of the European Economic Association, 9(4): 678-701. 
Masera, Federico. 2019. "Police Safety, Killings by the Police and the Militarization of US Law Enforcement." Available at https://papers.ssrn.com/sol3/papers.cfm?abstract_id= 3342922.

McCollister, Kathryn E., Michael T. French, and Hai Fang. 2010. "The cost of crime to society: New crime-specific estimates for policy and program evaluation." Drug and Alcohol Dependence, 108(1-2): 98-109.

Mello, Steven. 2019. “More COPS, Less Crime.” Journal of Public Economics.

Mummolo, Jonathan. 2018. "Militarization fails to enhance police safety or reduce crime but may harm police reputation.” Proceedings of the National Academy of Sciences, 201805161.

Rohlfs, C. 2010. "Does Military Service Make You a More Violent Person?: Evidence from the Vietnam Draft Lottery." Journal of Human Resources, 45: 271-300.

Sreenivasan, Shoba, Thomas Garrick, James McGuire, Daniel E Smee, Daniel Dow, and Daniel Woehl. 2013. "Critical concerns in Iraq/Afghanistan war veteran-forensic interface: combat-related postdeployment criminal violence." The Journal of the American Academy of Psychiatry and the Law, 41(2): 263-73.

Wooldridge, Jeffrey. 2000. Econometric Analysis of Cross Section and Panel Data. MIT Press. 